\title{
Research on the Spatial Distribution of Government Venture Capital Based on Location Entropy
}

\author{
Chang Guo
}

Economic college of Guizhou university of finance and economics, Guiyang, China

\begin{abstract}
In recent years, under the new normal economy, the government guide the main forms of venture investment funds in China fund scale expands unceasingly, this article from the government according to the present conditions of exploration and development of venture investment fund, using location entropy to calculate the guiding fund of regional agglomeration degree, and further analyzed the problems exposed by the fund size too quickly, and puts forward some countermeasures to improve.
\end{abstract}

\section{Keywords}

Government Venture Investment Guide Fund; Development Status Quo; Location Entropy

\section{基于区位熵的政府创业投资引导基金空 间分布研究}

郭畅

贵州财经大学经济学院，贵阳, 550025, 中国

摘要：近年来，在经济新常态下，作为我国政府引导基金主要形式的创业投资引导基金规模 不断扩大，文章从政府创业投资引导基金的探索与发展现状出发，运用区位熵计算出引导基 金的区域集聚度，并进一步分析了基金规模过快暴露出的问题，提出改善的对策。

关键词：政府创业投资引导基金；发展现状；区位熵 


\section{1. 引言}

创业投资具有高风险性、信息不对 称和正外部性等内在属性, 如果仅依靠 市场配置创业资本往往会面临市场失 灵。在财政新常态下, 为解决创新创业 的市场失灵问题, 贯彻落实市场在资源 配置中的决定性作用和更好发挥政府作 用，政府创业投资引导基金应运而生。

创业投资引导基金是指由政府设立 并按市场化方式运作的政策性基金, 主 要通过扶持创业投资企业发展, 引导社 会资金进入创业投资领域。引导基金本 身不直接从事创业投资业务。引导基金 的宗旨是发挥财政资金的杜杆放大效 应, 增加创业投资资本的供给, 克服单 纯通过市场配置创业投资资本的市场失 灵问题。特别是通过鼓励创业投资企业 投资处于种子期、起步期等创业早期的 企业，弥补一般创业投资企业主要投资 于成长期、成熟期和重建企业的不足。”

（《关于创业投资引导基金规范设立与 运作的指导意见》（国办发〔2008〕116 号））广义的政府引导基金是指由政府 设立的政策性基金，政府产业引导基金、
创业投资引导基金、科技型中小企业创 新基金等都属于这一范畴。狭义的政府 引导基金主要是指政府创业投资引导基 金。本文主要是指广义的政府引导基金 （以下简称 “引导基金” ）。

引导基金时推动我国创业投资和新 兴产业发展的重要实践, 是实现 “大众 创业、万众创新” 的助推器。但近年来, 随着引导基金规模不断扩大，功能不断 拓展，与原先的引导基金相比已呈现出 新的问题。鉴于此，对我国引导基金现 状进行全面分析, 找出引导基金发展过 程中存在的诸多问题, 才能对症下药, 促进引导基金的良性发展，充分发挥基 金的引导作用。

\section{2. 政府创业投资引导基金发展现状}

\section{1. 引导基金的设立概况}

据清科集团旗下私募通统计显示， 截至 2016 年, 政府引导基金已设立 1013 支, 总目标规模 53316.50 亿元, 已到位 资金达 19074. 24 亿元（见图 1)。其中, 仅 2016 年就新设立政府引导基金 384 支, 披露的总目标规模超过 3.1 万亿元。

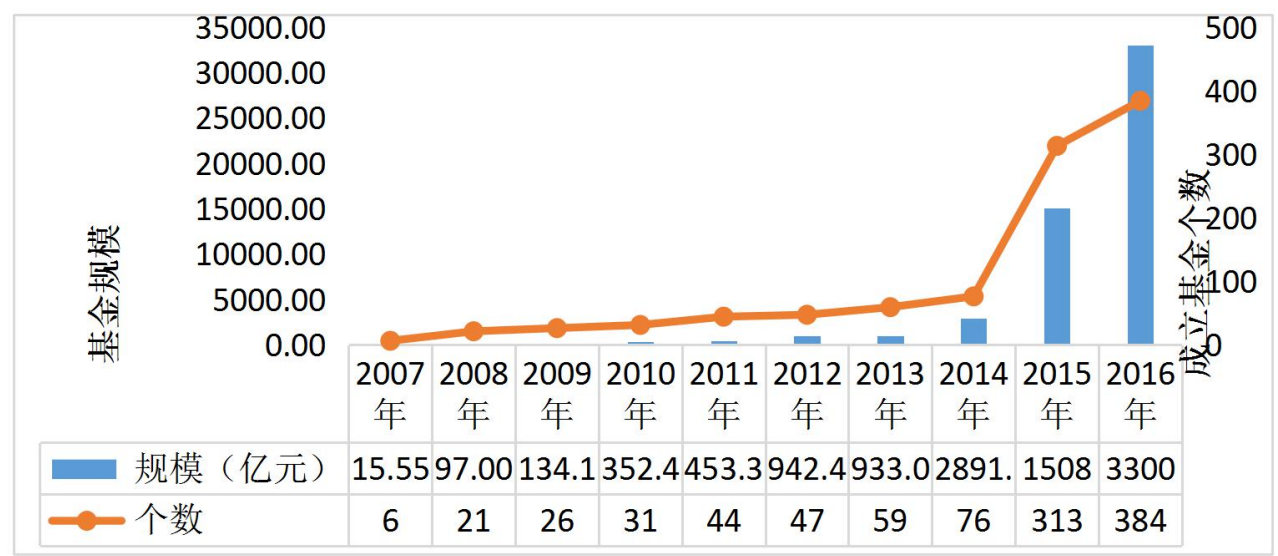

图 12007 年一 2016 年我国政府引导基金设立情况比较 资料来源：私募通 2017.4 


\section{2. 引导基金政策相继出台愈发完善}

从已颁布的政策办法来看, 无论是从 基金设立性质和宗旨，基金引导方式和 监管, 还是基金的考核方式等方面都有 了较为详细的规定。2005 年发布《创业 投资企业管理暂行办法》规定 “国家与 地方政府可以设立创业投资引导基金， 通过参股和提供融资担保等方式扶持创 业投资企业的设立与发展”，标志着我 国创业引导基金正式制度建设的开端。 2008 年发布的《关于创业投资引导基金 规范设立与运作的指导意见》从七大方 面明确了引导基金设立的性质和宗旨， 设立和资金来源，运作原则和方式，管 理及对引导基金的监管和引导, 对政府 引导基金各方面的问题都作出了规范。 为进一步规范政府创业投资资金管理， 2015 年发布《政府投资基金暂行管理办 法》，强化资金的透明化绩效预算评价 制度，明确基金募资、投资、投后管理、 清算、退出的市场运作方式。2016 年出 台的《关于政府资金注资政府投资基金 支持产资基金支持产业发展的指导意 见》进一步明确政府投资基金应按照 “政 府引导、市场运作、科学决策、防范风 险” 的原则进行运作。此外, 在完善引 导基金制度建设的同时，一系列税收优 惠，行政审批减免政策对社会创业投资 资本提供了优良的制度环境。

\section{3. 政府创业投资引导基金的空间分布}

\section{1. 变量定义与数据说明}

\section{1.1 变量定义}

本部分采用区位熵指数 (Location Quotient）衡量我国政府引导基金的区 域分布情况和集中程度。区位摘通常被 用于测量某一个区域要素的空间分布情 况, 用以反映某产业在某地区的专业化 程度, 以及某区域在高层次区域的地位 和作用。区位熵在实际应用中范围很广 泛, 也很有效, 是一个应用价值比较高 的指标。具体计算公式为:

$$
L Q_{i j}=\frac{e_{i} / e}{E_{j} / E}
$$

其中 $L Q_{i j}$ 表示某省第 $\mathrm{j}$ 年政府引导 基金的区位熵; $\mathrm{e}_{\mathrm{i}}$ 表示 $\mathrm{i}$ 省政府引导基 金规模; $\mathrm{e}$ 表示 $\mathrm{i}$ 省该年的财政支出规 模; $E_{j}$ 表示全国第 $j$ 年政府引导基金规 模; $\mathrm{E}$ 表示全国该年的财政支出规模。如 果 $L Q_{i j}=1$, 表明 $i$ 省的政府引导基金在第 $\mathrm{j}$ 年发展强度相当于全国政府引导基金 的平均水平; 如果 $L Q_{i j}<1$, 表明 $i$ 省的政 府引导基金在第 $\mathrm{j}$ 年发展强度低于全国 政府引导基金的平均水平; 如果 $\mathrm{LQ}_{\mathrm{ij}}>1$, 表明 $\mathrm{i}$ 省的政府引导基金在第 $\mathrm{j}$ 年发展 强度高于全国政府引导基金的平均水 平; 如果 $L Q_{i j}>1.5$, 说明发展强度在全国 具有显著的比较优势。

\section{1.2 数据来源与处理}

全国政府引导基金规模和各省政府 引导基金规模数据均取自清科集团旗下 私募通政府引导基金专题; 全国财政支 出和各省财政支出数据均来自国家统计 局网站公布的统计年鉴。为便于比较分 析, 将区域范围划分为中、东、西三个 部分, 不包含港澳台地区, 其中个别省 份的数据因没有或无较大规模的政府引 
导基金披露而未列出。

\section{2. 政府引导基金空间分布情况分析}

根据区位熵的公式及所需数据, 计 算出的 2012-2016 年中、东、西部地区 的区位熵如表 1 所示。

表 12012-2016 年中、东、西部地区政府引导基金 的区位熵值表

\begin{tabular}{|c|c|c|c|c|c|c|}
\hline \multicolumn{2}{|c|}{ 区域 } & 2012 & 2013 & 2014 & 2015 & 2016 \\
\hline \multirow{12}{*}{$\begin{array}{l}\text { 东 } \\
\text { 部 }\end{array}$} & 山东 & 1. 044 & 0.906 & 0.180 & 0.796 & 0.011 \\
\hline & 北京 & 0.444 & 2. 198 & 26. 990 & 1. 495 & 5. 539 \\
\hline & 江苏 & 1.879 & 1. 071 & 0.024 & 0.251 & 0.049 \\
\hline & 浙江 & 1.927 & 2. 527 & 0.161 & 0.598 & 0.081 \\
\hline & 福建 & 0.758 & 0.480 & 0.091 & 2.275 & 3. 034 \\
\hline & 上海 & 4. 759 & 0.362 & 0.033 & 0.846 & 7. 046 \\
\hline & 广东 & 2.954 & 1. 684 & 0.665 & 2. 139 & 1.866 \\
\hline & 广西 & 0.366 & -- & 0.159 & 0.018 & -- \\
\hline & 海南 & -- & - & 0.169 & 0.037 & -- \\
\hline & 河北 & 0.535 & 0.808 & 0.026 & 0.057 & -- \\
\hline & 天津 & -- & -- & 0.056 & -- & 0.026 \\
\hline & 辽宁 & 0.060 & - & -- & 7. 659 & 4. 268 \\
\hline \multirow{9}{*}{$\begin{array}{l}\text { 中 } \\
\text { 部 }\end{array}$} & 湖北 & 0.653 & 0.094 & 0.054 & 11.269 & 0.237 \\
\hline & 湖南 & -- & 4. 656 & 0.089 & 0.990 & 0.015 \\
\hline & 河南 & 0.872 & 8. 391 & 0.707 & 0.307 & 0.214 \\
\hline & 江西 & -- & - & -- & 0.063 & 1. 543 \\
\hline & 安徽 & 1.746 & 0.499 & 0.892 & 4. 571 & 0.145 \\
\hline & $\begin{array}{l}\text { 黑龙 } \\
\text { 江 }\end{array}$ & -- & -- & 0.706 & 0.229 & 3. 487 \\
\hline & 山西 & 10. 182 & 0.811 & 0.576 & 0.195 & -- \\
\hline & $\begin{array}{l}\text { 内蒙 } \\
\text { 古 }\end{array}$ & - & -- & -- & 0.043 & 1. 120 \\
\hline & 吉林 & -- & -- & -- & 0.222 & 1.903 \\
\hline 西 & 宁夏 & -- & -- & - & -- & -- \\
\hline 部 & 新疆 & -- & -- & - & 0.048 & 0.059 \\
\hline
\end{tabular}

\begin{tabular}{|c|c|c|c|c|c}
\hline 青海 & - & 0.067 & - & 0.487 & - \\
\hline 陕西 & 0.821 & - & 0.066 & 0.004 & 1.110 \\
\hline 甘肃 & 1.457 & - & 0.079 & 0.100 & - \\
\hline 四川 & 0.080 & - & 0.004 & 0.084 & 0.367 \\
\hline 云南 & 0.153 & 1.000 & - & - & - \\
\hline 贵州 & 0.396 & 1.930 & 0.274 & 0.418 & 0.534 \\
\hline 重庆 & -- & -- & 1.948 & 0.314 & - \\
\hline 西藏 & - & - & $-—$ & - & - \\
\hline
\end{tabular}

（注: “——”表示数据缺失）

在 2012 年至 2016 年 5 年间, 从各 个省区位熵结果上看: 广东（2.954, $1.684,2.139,1.866)$ 、北京 (2.198, $26.990,5.539)$ 、浙江 $(1.927,2.527)$ 、 福建（2.275，3.034）、上海（4.759, 7.046) 、辽宁（7.659, 4.268）、安徽 (1.746，4.571）、江苏（1.879）、湖 北（11.269）、河南（8.397）、江西 (1.543) 、黑龙江（3.487）、山西 (10.182)、吉林 (1.903)、贵州(1.930)、 重庆 (1.948) 16 省的区位熵在所对应年 份有大于 1.5 的情况, 表明这 16 个省的 政府引导基金的发展程度在全国具有显 著的比较优势。山东 (1.044) 、内蒙古 (1.120)、陕西 (1.110)、甘肃 (1.457)、 云南（1.000）5 省的区位熵在所对应年 份有大于或等于 1 的情况, 表明这 5 个 省的政府引导基金的发展程度较好, 具 有相对优势。其他省份区位熵小于 1 , 表 明这些省份的发展程度不及全国的平均 水平, 有待进一步发展。

根据上述分析可知, 政府引导基金 集聚度相对较高的省份主要集中在东部 地区, 广东省的集聚度居全国首位。东 部地区的集聚度较高, 与这些地区整体 经济发展水平高, 高精尖人才集聚, 信 
息资源比较发达有着密切的关系。其次 是中部地区, 政府引导基金发展具有一 定的集聚趋稳趋势。西部地区的区位摘 值总体较低, 大部分省份区位熵小于 1 , 需要更多的投入和扶持。

\section{4. 结束语}

综上可知, 近年来随着引导基金政 策规范化和创业环境的不断优化, 政府 创业投资引导基金对创新型和科技型企 业的杜杆和引导效应显著。但同时在实 践过程中一些问题也在不断显现。

首先, 地区分布不均衡。在经济相 对发达的北上广深、苏浙等地, 政府引 导基金聚集程度高, 发展速度快, 同时 已开始深入市级甚至区县级单位。相比 较而言, 中西部地区引导基金的起步时 间晚, 设立的引导基金相对较少。针对 这样的差异性, 可考虑与各地政府建立 创业投资项目信息库，增加欠发达地区 被投资机会。

其次, 引导基金结存现象突出。据 国家审计署于 2016 年发布的《国务院关 于 2015 年度中央预算执行和其他财政收 支的审计工作报告》中显示, 通过审批 的 206 个自基金中, 有 39 个因未吸引到 社会资本无法按期设立, 13.67 亿元财政 资金滞留托管账户; 已设立的 167 个子 基金募集资金中有 148.88 亿元 (占 41\%) 结存未用, 其中 14 个从未投资, 造成资 源的大量浪费。因此, 在政策的制定中 应进一步明确引导基金的功能定位, 各 级政府在设立引导基金时，应结合当地 实际情况，合理控制引导基金的规模与
投向。

第三, 绩效考核制度不健全。目前, 大多数政府引导基金尚未建立完善的基 金绩效考核体系，即使小部分引导基金 实行了绩效考核, 也是相当宽泛, 对于 如何监管以及具体考核体系并未作出详 细的办法规定。绩效评价体系的建立和 完善, 应从合规、管理、效益等多角度、 全方位、立体地对相关人员和机构进行 考核, 努力做到政策效益和经济效益的 兼顾。

\section{参考文献}

[1] 马海涛, 师玉朋, 政府创业投资引导 基金发展现状与制度改进, 地方财政 研究, 2016（5）：4-8.

[2] 孙雯, 张晓丽, 邱峰, 政府引导基金 发展现状及其推进策略, 国际金融, 2017（7）：75-80.

[3] 朱文莉, 刘思雅, 政府创业投资引导 基金发展现状、问题及对策, 会计之 友, 2014（2）：43-47.

[4]清科研究中心, 《2016 年政府引导基 金报告》发布, 管理办法支持四大领 域、明确负面清单 [EB/OL]. http://free. pedata. cn/1 4409984 36840710. html. 